\title{
Reaching out to the Mature Learner- A New Direction for Canadian Universities
}

\author{
WALTER PITMAN*
}

\begin{abstract}
"The Learning Society", the Report of the Commission on Post-Secondary Education in Ontario, has been surrounded by controversy. Quite expectedly and properly, universities reacted most strongly against what they considered to be a detrimental change in the structuring of the relationship between the Ontario Government and the post-secondary institutions within its jurisdiction. So far, there has not been sufficient debate about the far-reaching proposals which will create a learning society, and the validity of the assumptions on which these proposals are based.
\end{abstract}

One example of questionable wisdom is the recommendation that there should be a massive expansion of part-time adult education with store-front universities in smaller communities and an open university associated with educational television and other technological developments. The justification of these new directions is that of assuring access to every potential mature student in the province. The assumption on which this proposition is based raises the eye-brows of many involved in continuing education in this country. Are there hundreds of thousands of unserviced people hungering for the university experience (to say nothing of the accompanying assumption that these methods would indeed transmit a university experience at a viable cost)? There is also the unexpressed faith that the highly structured courses and programs presently offered and related essentially to the acquisition of credit and subsequently to the preparation of professionals is relevant to so many of those whose presence in the university has been divined to be of benefit to themselves, to their society and even to the university itself. The Commission does not really cope with these basic problems.

Yet, in these days of steady-state enrolment and in the realization that the numbers of students graduating from Ontario high schools over the next decade will not increase, there is every possibility that universities may find it financially attractive to seek out a more varied clientele than that which has been found on the campus in the recent past.

Although the rapid expansion of the system in the ' 60 's was undoubtedly detrimental to the ordered development of university programs, there are fears of stagnation and debilitation if universities have to wind down by dropping programs, letting faculty go and undermining institutional capacity to cope with future needs. As well, there is the

*Walter Pitman is Dean of Arts and Science at Trent University, Peterborough. 
deleterious effect on the future of those scholars who were produced in that frantic decade if no further employment as academics can be expected in the '70's and '80's. Most institutions would see a strengthening in a limited, controlled growth, based on reaching out to groups of people as yet unserved, if it could be accomplished in an academically valid manner. On the other hand, it would be tragic if financial exigency led universities to develop a veritable circus of activity with the aim of attracting income, but with little relevance to the institutions' fundamental purpose, or the skills and experience of those who have been gathered to form their faculties.

It was with these fears and concerns in mind that members of the administration and faculty at Trent University began to consider the possibility of contacting one group in our society-those who have retired from their life vocation and might be interested in the intellectual activities transpiring on a university campus. (1)

A week-long seminar, funded by a grant from the New Horizons Program of the federal government, was organized to include a widely representative group of about 30 retired persons and their wives, some of whom had been professionals, others who had worked in factories and offices, others who had been small businessmen. A third of the group were from outside Peterborough, lived in student residences and thereby sampled another aspect of university life. The purpose of this event was simple-to assist one university and, possibly in the long run, the university system as a whole, to discover whether a valid continuing program could be mounted which would serve at least certain retired people in the Ontario community. During the week, a number of programs were attempted, including an introductory lecture in a number of areas that have more recently received attention in universities-Native Studies, Canadian Literature, as well as an "up-dated" look at the physical and social sciences. Some of these mornings were given over to special topics such as the economics of aging, the senior citizen in the community-topics felt to be of particular interest to this age group. The program began each morning at nine and was not completed until eight in the evening. Although each morning was devoted to a special program, as outlined above, the afternoons were left free for participants to partake of lectures and seminars taking place as part of the regular program of the university. They were encouraged to spend time in the common rooms, chatting with students, and to have meals with students in the college dining halls. Each evening the group re-convened to discuss the day's activities and make recommendations. Friday morning, the last day of the seminar, was spent pulling all of the material together and discussing models for programs for retired people which could be developed in a university setting.

There were many conclusions one came to as a result of this experience. First, there will be a small number, but a very small number, who will be interested in the credit program of the university. The reasons are obvious-only a small percentage of those of an age to be retired have formal academic training, sufficient to be comfortable in a university class. As well, the existing courses are part of a pattern of program development leading to a certain proficiency in a particular discipline, and although certain individual courses have undoubted intrinsic interest, the fact that they are components in a larger learning program, has its disadvantages to those uninterested in credits or qualifications but anxious to gain a wider understanding of the world they have lived in for six or seven decades. There seems to be a real argument for special courses and programs, probably 
inter-disciplinary and intensive in terms of time, which would make use of the life experience of participants as an aspect of teaching method and offered by the university on a non-credit basis, but at a credit level of academic expectation. Some universities have opened up their credit offerings to senior citizens by removing all tuition fees, and although this will be a boon to a few, it should not be considered as the definitive role the university can play in providing legitimate services to this sector of society.

As well, there was intense interest in the model of a shorter, compact, residential learning program to which "Senior Students" might be attracted. There was a feeling that a program which combined offerings directed specifically at the problems of this age group -in co-ordination with offerings more related to the traditional academic program of the university, would serve a real need, arousing interest in reading, research and study of contemporary problems. It should be open to both single men and women, but more important, directed to married couples.

In every case, participants in the Trent program expressed a clear preference for any course developments which allowed maximum contact with younger students. This was an element which the organizers of the Trent seminar had not realized clearly at the outset and as a result regular students were not formally involved in the planning. There was an extraordinary informal interaction which was appreciated by both young students and the retired citizens. There were some exciting insights gained when a former Minister of Welfare in the Saskatchewan C.C.F. Government turned up in a Politics seminar on "Third Parties". A man who had spent 42 years in a Montreal garment factory had some interesting observations when invited to a Sociology class. There is reason to believe that the university community would be psychologically healthier for having the total spectrum of age and experience in its midst. In fact, one of the participants saw great possibilities in having regular students aware of the economic plight and the social disadvantages of the elderly as an aspect of certain discipline studies. The participants concluded that the format of an intensive program of full-time attendance and residential living for a week or two would be particularly valuable for those about-to-be retired. It could be a preparation for what has become a rather traumatic event and could be made a part of the personnel policy of progressive corporations that every employee approaching retirement, along with his or her spouse, could partake of such an experience. Trent University will, in fact, be seeking federal funding for week-long seminars for pre-retirement in the spring of ' 74 , and it is hoped to widen the spectrum of participation to include representatives of the personnel services in the corporate world, as well as the educational and municipal service areas. A model for future programs will emerge from this process as it did from the seminar for retired persons.

One conclusion was brought home as a result of the Trent seminar-that most of those who were retired bring a different "mind set" to academic studies. Some retired individuals, especially those who have been involved in a self-learning process throughout their lives, may find it quite acceptable to continue in the regular pattern of university studies. However, the "I know it and I will tell you" lecture-demonstration approach is probably least appropriate to that age group. People who have raised and supported a family, successfully held a job of some responsibility, have some reason to believe that they have contributions to make in any examination of human reality, particularly in the humanities and so- 
cial science. The effective marshalling of the experience of the retired as a feature of a program is essential and may be the central dynamic of any success in this field. University faculty, whose teaching has been at the undergraduate level with teenage students, will find the experience of dealing with retired people even more harrowing (but exciting) than teaching the normal run of adult students who, too often, will jump through the hoop willingly in order to capture the all-important credit which may mean a raise in pay back-on-the-job.

Another reality is that learning for older persons is very much "personal problemoriented". There was some concern in the first day of the Trent seminar that no specific economic and social goals were to be stressed and that no strategy for making the seminar a pressure group to improve the lot of senior citizens in our land had been contemplated. It was made apparent by faculty that the university had no expertise in matters of pensions, senior citizens' housing and recreation and most participants accepted this candour, but the problems of retirement continually surged forward in any number of discussions on appropriate educational development for retired people.

There will be those who will say that the community college, with its openness and commitment to part-time education, with less commitment to research and academic values, might be able to serve such people more effectively. There are many retired who would indeed be welcomed in the community college setting and whose interests in arts and crafts or hobbies could be fulfilled in the facilities and by the skills of those who serve in colleges of applied arts and technology. But to characterize the senior citizen (a designation, incidentally, resented by those who spent a week at Trent) as one who would not benefit from the more philosophic, contemplative studies found in a liberal arts faculty of a university, is to do a segment of that group a gross injustice. The noted historan, W.L. Morton, made the observation that with the new presentism and extraordinary concern for immediate vocational goals which has characterized the post-secondary learning choices of young people, the adult, and particularly the more mature adult student, might well be the "scholar" who represents the traditional raison d'etre of the university. In any case, the community college focus is sufficiently strong in the direction of preparing people for immediate job opportunities that it may not be relevant to the interests of many retired, and, finally, the fact that residential accommodation is not available on many community college campuses results in a significant loss, in so far as some programs are concerned.

There has been a long tradition of peripheral interest in the pre-retirement education and the provision of learning opportunities for retired persons in North America. The University of Chicago traces its interest in this field back to 1951 and today the Industrial Relations Center of that university presents a program entitled "Making the Most of Maturity" which is offered to industries throughout the United States who may wish to participate. The University's Union and Research and Education Projects Unit presents a program called "Looking Ahead to Retirement" and trade unions are offered an opportunity to involve themselves by sending representatives. In 1948 the University of Michigan developed a program with the purpose of assisting people to adjust to all the pressures of aging and retirement. Later it came to include courses to train union and management personnel who might become involved as discussion leaders for pre-retirement programs. 
There has been some research which has attempted to assess the value of such preretirement education with cautiously encouraging results. (2)

Programs for citizens who have already retired can be found in a few American institutions. In most cases the programs are simply part of the general outreach to mature individuals in the community, usually combined with all the non-credit offerings for the mature person. However, older adults at Boston University and Antioch College are granted free or lowered tuition in the regular credit programs. Special seminars of particular interest to older citizens are offered by the University of Akron in a series entitled "An Afternoon at the University". (3)

Perhaps the most intense commitment to this group in our society can be found at the University of Kentucky. In 1962, a Council on Aging was formed by the Trustees of the University and responsibility for the development of a program in this area was assigned to the Department of University Extension. The purpose of the Council was stated as "teaching and research that has as its purpose the improvement of health and productivity of senior citizens of the Commonwealth and the Nation".

At each semester, 150 students who are 65 years and over are registered and financial support is provided through the Herman L. Donovan Fellowships for Senior Citizens. The Donovan scholars pay no fees for regular university credit courses and they attend regular courses with younger students. However, there are special continuing education classes for older persons as part of the program, one related to Art education and the Forum on Aging and other educational programs are associated with the university, including Retirement Planning and Counselling, Writing Workshop for People Over 57, and the Sciences and Aging Seminar. (4)

The Donovan Program at the University of Kentucky leads to a problem which faces Canadian universities at a time of restrained budgets-how does one finance such a project? Pre-retirement programs could surely be funded in part by responsible corporations as a part of their personnel benefit package. Trade unions might be another source of contribution and, of course, a system of shared employer-employee contributions might become part of the negotiated union-management settlement along with wages, pensions and health insurance schemes. Yet one must remember that only one-third of Canada's employees are covered by union negotiated agreements.

The retired citizen represents a different problem. Certainly, most of them have seen their personal financial situation deteriorate dramatically once their employment ends. At a time of inflationary pressures, only a major commitment on the part of provincial or federal governments through a scholarship program, not unlike that of the University of Kentucky, will cope with the intellectual needs of retired persons. It is either that or provincial extra-formula support which will allow one of two universities at least the financial base to mount quality programs, including residential costs for those coming from a distance. Surely, if the learning society is to become a reality, it must serve the specific needs of a variety of groups and those who are approaching the end of their working years, and those living the final third of their time deserve the attention of any government committed to these social policies.

In the year 1974, the university feels somewhat defensive about its role. For reasons with which the university has little to do, the expectations which many young people and 
their parents had about the value of the university education have been unfulfilled. The institution itself is no longer the favourite of politicians who once saw their narrow interests served by the well-being of their local university or college. If the university can rearrange, re-direct and re-focus the learning patterns in such a way that older, retired individuals may find fulfilment, the road back to a restoration of public confidence may have been discovered.

There may be other societal advantages. There are immense unfilled needs in every community-social, recreational, services which go begging and increase the sum-total of heartache and suffering. The experience and wisdom of several decades, honed and directed by the studies available in a university, might focus leadership and fill the void so desperately apparent in many communities.

The '60's have left those in education battleworn and shell-shocked and any call to change or improve the world is met with a degree of cynicism. Nonetheless, there may well be a role for the university in serving the senior student in the days ahead-a role which will enhance its academic commitments and improve its capacity to serve the wider community.

\section{Notes}

1 "Retired Citizens in Residence," A Report of the Program, November 4-9, 1973, Trent University.

2 Woodrow W. Hunter, A Longitudinal Study of Preretirement Education, Division of Gerontology, University of Michigan, U.S. Department of Health, Education and Welfare, Welfare Administration, Research Grants Branch, Project 151, 1968.

3 Andrew Hendrickson, The Role of Colleges and Universities in the Education of the Aging, in Potentialities for Later Living, Report of the Seventeenth Annual Southern Conference on Gerontology, University of Florida, February 4-6, 1968.

4 Pamphlet issued by University Extension, Council on Aging Program, 345 Columbia Avenue, University of Kentucky, Lexington, Kentucky, 40506. 